
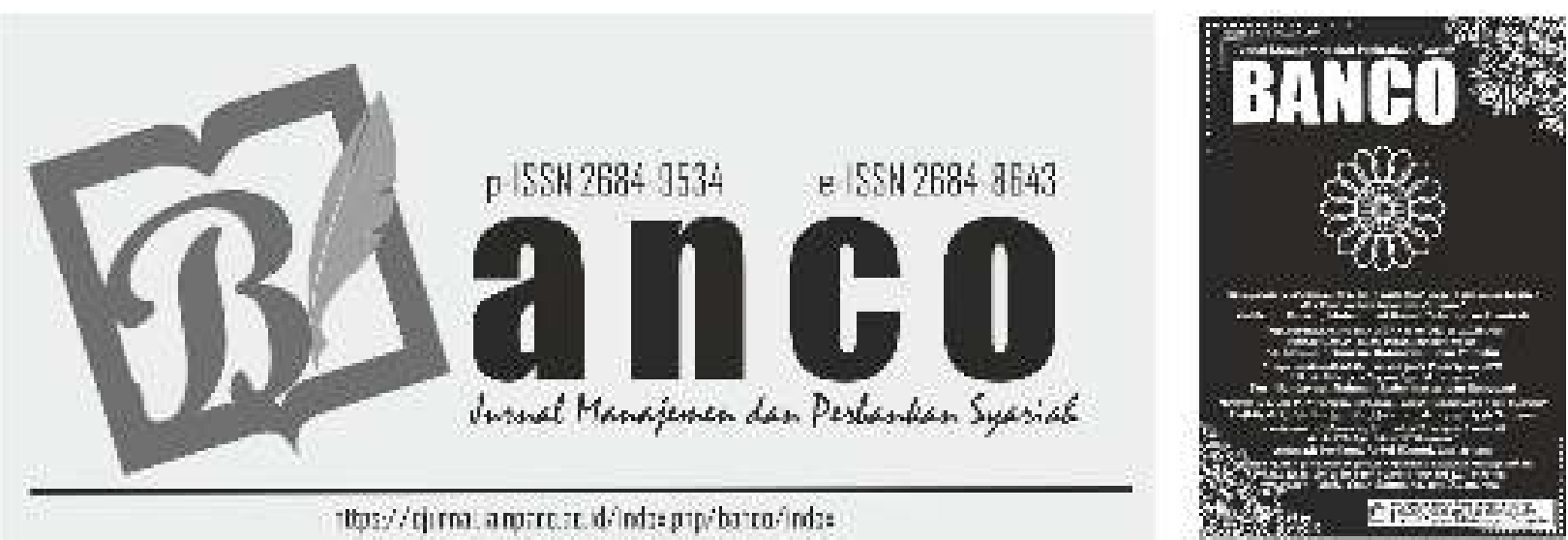

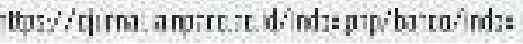

\title{
HARGA JUAL DAN TINGKAT MARGIN: PREFERENSI NASABAH DALAM MENGGUNAKAN PRODUK PEMBIAYAAN MURABAHAH BMT AS'ADIYAH SENGKANG
}

\author{
Reni Furwanti \\ Universitas Islam Negeri (UIN) Sunan Kalijaga Yogyakarta \\ renifurwanti96@gmail.com
}

\begin{abstract}
This paper will discuss the effect of the price cost and the level of margins to the customer's decision to use murabahah product in BMT As'Adiyah Sengkang. The purpose of this paper is to find out whether the price cost and the level of margins have a significant effect to the customer's decision to use murabahah product in BMT As'Adiyah Sengkang. This type of research uses quantitative research with descriptive statistical analysis and will be interpreted by using multiple linear regression tests. The results show, simultaneously, the price cost and the level of margins have a significant effect to the customer's decision to use murabahah product in BMT As'Adiyah Sengkang. But partially the price cost has a significant effect while the margin does not..
\end{abstract}

Keywords: Cost of goods, Margin, BMT

\begin{abstract}
Abstrak
Penelitian ini akan membahas tentang pengaruh harga jual dan tingkat margin terhadap keputusan pelanggan untuk menggunakan produk murabahah BMT As'Adiyah Sengkang. Tujuannya adalah untuk mengetahui apakah biaya barang dan tingkat margin memiliki pengaruh yang signifikan bagi pelanggan menggunakan produk murabahah di BMT As'Adiyah Sengkang. Jenis penelitian ini menggunakan jenis penelitian kuantitatif dengan menggunakan analisis statistik deskriptif dan akan ditafsirkan menggunakan uji regresi linier berganda. Hasil penelitian menunjukkan, secara simultan, harga jual dan tingkat margin memiliki pengaruh yang signifikan terhadap pengambilan keputusan tentang pembiayaan murabahah BMT As'adiyah Sengkang. Namun secara parsial harga jual berpengaruh signifikan sedangkan margin tidak berpengaruh terhadap keputusan nasabah
\end{abstract}

Kata kunci : Harga jual, Margin, BMT

Author correspondence email: renifurwanti96@gmail.com

Available online at: https:// doi.org/10.35905/banco.v2i1.1331 


\section{Reni Furwanti}

\section{A. Pendahuluan}

BMT merupakan lembaga keuangan mikro yang dioperasikan dengan sistem bagi hasil atau profite sharing, jual beli, dan sistem lainnya yang sesuai dengan prinsip- prinsip syariah untuk menumbuh kembangkan bisnis usaha mikro dan kecil dalam rangka mengangkat drajat dan martabat serta membela kepentingan masyarakat menegah dan kecil. Dikalangan masyarakat menegah dan kecil, BMT merupakan lembaga keuangan syariah yang paling terjangkau serta sarana yang paling mudah untuk memenuhi kebutuhan akan dana pinjaman.(Harahap \& Ghozali, 2020)

Dalam skala mikro, BMT mampu mengurangi jalannya Bank Konvensional yang menarik dana masyarakat lalu dipinjamkan kepada konglomerat dan pengusaha besar. Hal tersebutlah yang melatarbelakangi hadirnya BMT untuk membantu mengikis praktek rentenir yang sudah menjamur dimasyarakat. Syaifuddin A. Rasyud mengemukakan bahwa Baitul Mal wa Tamwil (BMT) adalah kelompok swadaya masyarakat sebagai lembaga ekonomi rakyat yang berupaya mengembangkan usaha- usaha produktif dan investasi dengan sistem bagi hasil untuk meningkatkan kualitas ekonomi pengusaha kecil bawah dan kecil dalam upaya pengetasan kemiskinan.(Sudjana \& Rizkison, 2020)

Salah satu produk yang ditawarkan oleh BMT adalah pembiayaan murabahah yakni jual beli barang pada harga asal dengan tambahan keuntungan yang telah disepakati. Dalam murabahah, penjual harus memberi tahu harga jual produk yang ia beli dan menentukan suatu tingkat keuntungan sebagai tambahannya. Pembiayaan murabahah ini diatur dalam Fatwa Dewan Syariah Nasional pada Nomor 4/DSNMUI/IV/2000 Tanggal 1 April 2000 tentang murabahah. Murabahah sangat erat kaitannya dengan harga jual dan tingkat margin(Sakum, 2021). Di mana harga merupakan aspek yang sangat penting dalam kegiatan pemasaran. Harga menjadi sangat penting karena menentukan laku atau tidak suatu produk barang atau jasa tersebut. Jika dalam menentukan suatu harga mengalami kesalahan, maka nantinya akan berakibat fatal dan merugikan perusahaan itu sendiri. Harga jual terdiri dari harga barang itu sendiri dan biaya-biaya yang dikeluarkan untuk memperoleh barang tersebut dari supplier. Penentuan tingkat margin dititik beratkan pada keputusan pemangku kekuasaan tertinggi selain dari pertimbangan- pertimbangan lain. Di mana pihak lembaga keuangan menjelaskan mengenai penentuan tingkat margin kepada nasabah, namun tidak menutup kemungkinan beberapa nasabah terkadang belum paham tentang prosedur penetapan margin yang ditetapkan pada lembaga keuangan yang terkait(Makkulau \& Abdullah, 2017).

Nisa Alvi Sa'ada dalam penelitiannya yang berjudul "Pengaruh penetapan harga jual dan tingkat margin terhadap keputusan pembiayaan murabahah pada anggota BMT Agritama Blitar" dikemukakan bahwa harga jual dan margin berpengaruh positif dan signifikan terhadap keputusan pembiayaan murabahah pada BMT Agritama Blitar. Hal tersebut mengindikasikan bahwa ketika kedua indikator dalam penelitian tersebut yakni harga jual dan margin mengalami perubahan baik berupa kenaikan ataupun penurunan akan menjadikan nasabah semakin selektif dalam menentukan pilihannya untuk menggunakan pembiayaan murabahah atau tidak. Sehingga semakin tinggi harga jual dan tingkat margin maka akan semakin berkurang minat nasabah pembiayaan murabahah dan begitupun sebaliknya.(Djuwita \& Purnamasari, 2017)

Fadlan Hotomatul Adalah dalam penelitiaanya yang berjudul "Pengaruh potongan margin (Muqashah ArRibhi) terhadap minat nasabah dalam memanfaatkan pembiayaan murabahah di Bank Pembiayaan Rakyat Syariah (BPRS) Bhakti Sumekar (Studi kasus Kantor Cabang Bluto Sumenep)" mengemukakan bahwa potongan margin berpengaruh positif terhadap minat nasabah. Hal ini mengindikasikan bahwa nasabah cenderung memilih pembiayaan dengan margin terendah untuk memperoleh nilai guna yang maksimal. Margin merupakan daya tarik tersendiri bagi preferensi nasabah pada BPRS terkait(Adalah \& Fadllan, 2016).

Aishath Muneeza, Muhammad Fahmi Fauzi, et all dalam penelitiannya yang berjudul "House financing: contracts used by islamic banks for finished properties in Malaysia" dikemukakan bahwa orientasi pembiayaan 
murabahah lebih banyak dialokasikan untuk membiayai aspek properti. Mayoritas bank di Malaysia menganggap bahwa murabahah telah mendapatkan popularitas melalui Bursa Suq Al- Sila yang dianggap mudah, cepat, dapat diandalkan, menguntungkan, lebih murah, nyaman dan tidak memiliki risiko untuk melakukan transaksi jenis.(Muneeza et al., 2020)

Dalam proses penentuan harga jual, bank syariah masih bergantung pada beberapa faktor layaknya bank konvensional, yaitu suku bunga yang dikeluarkan oleh Bank Indonesia dan beban keuntungan bagi pihak bank/BMT, pemilik modal, serta nasabah penyimpan(Millah \& Ayik Andriani, 2021). Sedangkan dalam penentuan tingkat margin terkadang dalam lembaga keuangan syariah penetapannya masih ditentukan oleh lembaga tersebut, dikarenakan beberapa nasabah belum paham tentang berapa margin yang sesuai pada saat ini. Zuriati Yakabera dalam hasil penelitiannya mengemukakan bahwa penetapan harga jual dan tingkat margin tidak berpengaruh signifikan terhadap keputusan nasabah pembiayaan murabahah baik secara simultan maupun pasrial.(Ajmi et al., 2019)

Kopsyar BMT As'adiyah Sengkang lahir berdasarkan tuntutan dan animo masyarakat yang ingin menjadikan BMT sebagai wadah untuk mengembangkan usaha ekonomi syariah dalam rangka mencapai kesejahteraan. Oleh karena itu Kopsyar BMT As'adiyah Sengkang yang merupakan lembaga keuangan mikro syariah dalam menjalankan usaha yang berbasis ekonomi kerakyatan dan berpolakan syariah, tumbuh dan berkembang dari arus bawah untuk menggali dan menumbuhkembangkan serta memperdayakan ekonomi lemah terhadap himpitan sistem spekulasi dan praktek-praktek ribawi atau rentenir.(Furwanti, 2020)

Berangkat dari realitas penyaluran dana BMT As'adiyah Sengkang, dapat diketahui bahwa BMT As'adiyah Sengkang didirikan pada tanggal 10 Juni 2001 dan sudah beroperasi selama \pm 19 tahun dan masih eksis hingga saat ini. Di mana kopsyar BMT As'adiyah Sengkang ini dianggap layak dan mampu bersaing dengan lembaga keuangan lainya dikarenakan jangkauan pemasaran BMT As'adiyah cukup luas yakni meliputi wilayah Kec. Tempe, Tanasitolo, Pamanna dan beberapa wilayah lain yang berdomilisi di daerah Kab. Wajo dan sekitarnya. Adapun jumlah anggota/ nasabah pembiayaan selama Tahun 2019 adalah 272 nasabah. Dari berbagai faktor yang mempengaruhi konsumen dalam melakukan pembelian suatu produk atau jasa, biasanya konsumen selalu mempertimbangkan kualitas, 8 harga dan produk sudah yang sudah dikenal oleh masyarakat sebelum konsumen memutuskan untuk membeli.(Fathorrahman \& Nufus, 2021)

Berdasarkan beberapa uraian di atas, fokus penelitian yang akan diteliti adalah pengaruh harga jual dan tingkat margin terhadap pengambilan keputusan pembiayaan murabahah pada BMT As'adiyah Sengkang. Penelitian ini dianggap penting untuk dilakukan karena harga jual dan tingkat margin dapat mempengaruhi keputusan nasabah dalam mengambil pembiayaan murabahah, jika harga jual dan tingkat margin terlampau tinggi maka nasabah akan cenderung memilih lembaga keuangan lain.(Millah \& Ayik Andriani, 2021) Sebaliknya jika harga jual dan tingkat margin telalu rendah maka pihak BMT tidak mampu menutupi biaya operasional dari pencairan dana pinjaman. Di mana yang membedakan penelitian ini dengan penelitian sebelumnya yakni penelitian ini akan diititik beratkan pada seberapa besar pengaruh harga jual sebagai penentu awal perumusan harga jual serta tingkat margin sebagai persentasi keuntungan yang diperoleh pihak pemberi dana dalam hal ini BMT As'Adiyah Sengkang terhadap persepsi nasabah yang selanjutnya akan mengambil keputusan untuk menggunakan/ tidak menggunakan produk pembiayaan murabahah di BMT terkait.(Melina, 2020)

\section{B. Diskusi dan Pembahasan}

\section{Hasil Uji Validitas dan Reabilitas}

Uji validitas dilakukan untuk mengetahui apakah instrument valid dan reable untuk diterapkan dalam penelitian. Dasar pengambilan keputusan dalam uji validitas adalah jika $\quad r_{\text {hitung }}>r_{\text {tabel }}$ maka item pertanyaan berkorelasi signifikan terhadap skor total, begitupun sebaliknya jika $\mathrm{r}_{\text {hitung }}<\mathrm{r}_{\text {tabel }}$ maka 


\section{Reni Furwanti}

item pertanyaan tidak berkorelasi secara signifikan terhadap skor total. Item kuosioner yang valid dapat dijadikan acuan untuk penelitian selanjutnya.(Yusup, 2018)

Tabel 1: Output Hasil Uji Validitas

\begin{tabular}{|l|c|c|c|c|}
\hline \multicolumn{1}{|c|}{ Variabel } & Item Pernyataan & $\mathbf{r}_{\text {hitung }}$ & $\mathbf{r}_{\text {tabel }}$ & Keterangan \\
\hline \multirow{3}{*}{ Harga jual(X1) } & 1 & 0,482 & 0,223 & Valid \\
\cline { 2 - 5 } & 2 & 0,819 & 0,223 & Valid \\
\cline { 2 - 5 } & 3 & 0,702 & 0,223 & Valid \\
\cline { 2 - 5 } & 1 & 0,720 & 0,223 & Valid \\
\cline { 2 - 5 } & 2 & 0,720 & 0,223 & Valid \\
\hline Tingkat Margin(X2) & 3 & 0,808 & 0,223 & Valid \\
\cline { 2 - 5 } & 1 & 0,605 & 0,223 & Valid \\
\cline { 2 - 5 } & 2 & 0,507 & 0,223 & Valid \\
\cline { 2 - 5 } & 3 & 0,715 & 0,223 & Valid \\
\cline { 2 - 5 } & 4 & 0,514 & 0,223 & Valid \\
\cline { 2 - 5 } & 5 & 0,270 & 0,223 & Valid \\
\hline
\end{tabular}

Sumber data primer: diolah tahun 2019

Hasil uji validitas menunjukkan 3 variabel (harga jual/ $\mathrm{X}_{1}$, tingkat margin/ $\mathrm{X}_{2}$ dan pengambilan keputusan pembiayan murabahab/Y) pada penelitian ini adalah valid karena 10 dari 11 item pertanyaan diperoleh $r_{\text {hitung }}>r_{\text {tabel }}$ dengan dengan level correlation significant 0,01 . Sedangkan 1 dari 11 pertanyaan berada pada level correlation significant 0,05 .

Tabel 2: Uji Reablitas

\begin{tabular}{|l|l|l|}
\hline \multicolumn{1}{|c|}{ Variabel } & \multicolumn{1}{|c|}{ Combach's Alpha } & \multicolumn{1}{c|}{ Keterangan } \\
\hline Harga jual(X1) & 0,419 & Realibel \\
\hline Tingkat Margin(X2) & 0,642 & Realibel \\
\hline Keputusan Nasabah $(\mathrm{Y})$ & 0,364 & Realibel \\
\hline
\end{tabular}

Sumber data primer: diolah tahun 2019

Dasar pengambilan keputusan yang digunakan dalam uji reabilitas pada penelitian ini yaitu jika Combach's $A l p h a>\mathrm{r}_{\text {tabel. }}$. Maka dapat diketahui hasi uji reabilitas pada penelitian ini adalah reable dengan alasan sebagai berikut :

a. Total item pertanyaan pada variabel harga jual $\left(\mathrm{X}_{1}\right)$ memperoleh nilai alfa 0,419. Artinya Combach's Alpha $>\mathrm{r}_{\text {tabel }}(0,419>0,295)$ sehingga variabel $\mathrm{X}_{1}$ dinyatakan reable.

b. Total item pertanyaan pada variabel Tingkat Margin $\left(\mathrm{X}_{2}\right)$ memperoleh nilai alfa 0,624. Artinya Combach's $A l p h a>\mathrm{r}_{\text {tabel }}(0,624>0,295)$ sehingga variabel $\mathrm{X}_{2}$ dinyatakan reable.

c. Total item pertanyaan pada variabel pengambilan keputusan pembiayaan murabahah (Y) memperoleh nilai alfa 0,364. Artinya Combach's $A$ pha $>\mathrm{r}_{\text {tabel }}(0,365>0,295)$ sehingga variabel $\mathrm{X}_{1}$ dinyatakan reable.

\section{Hasil Uji Asumsi Klasik}

Uji normalitas dimaksudkan untuk mengetahui apakah data yng di uji berdistribusi normal atau tidak. Pengujian normalitas dilakukan dengan tehnik kolmogrof-Smirnov dengan kriteria jika nilai signifikansinya $>0,05$ maka berdistribusi normal, namun jika nilai signifikansinya $<0,05$ maka data tersebut bedistribusi tidak normal. Hasil uji normalitas berdasarkan output di atas menunjukkan bahwa nilai signifikansi $>0.05(0,105>0,05)$, artinya data yang diuji adalah berdistribusi normal. 
Uji linearitas dimaksudkan untuk mengetahui apakah hubungan antara variabel dependen dengan masing- masing variabel independen dalam penelitian ini memiliki hubungan yang linear atau tidak. Untuk memastikan data bersifat linear atau tidak, dapat dilakukan degan melihat nilai signifiknsi linearitynya, apabila $>0,05$ maka terdapat hubungan linear secara signifikan antara variabel independen dengan variabel dependen begitupun sebaliknya. Di mana dalam penelitian ini menujukkan hasil uji lineritas antara variabel harga jual $\left(\mathrm{X}_{1}\right)$ dengan pengambilan keputusan pembiayaan murababah (Y) adalah signifikan $(0,260>0,05)$. Begitupun dengan uji linearitas variabel tingkat margin $\left(\mathrm{X}_{2}\right)$ dengan pengambilan keputusan pembiayaan murabahah (Y) adalah tidak signifikan $(0,00<0,05)$. Meskipun variabel tingkat margin $\left(\mathrm{X}_{2}\right)$ dengan variabel pengambilan keputusan pembiayaan murabahah $(\mathrm{Y})$ tidak signifikan, akan tetapi hubungan antara variabel harga jual $\left(\mathrm{X}_{1}\right)$ dengan variabel pengambilan keputusan pembiayaan murabahah (Y) memiliki sifnifikansi yang cukup tinggi sehingga dapat memenuhi syarat untuk melakukan analisis regresi linier berganda.

Uji multikolonearitas bertujuan untuk mengetahui apakah dalam model regresi ditemukan adanya korelasi antar variabel independen. Dalam model regresi yang baikseharusnya tidak terjadi korelasi antar variabel independen. Pengambilan keputusan dalam uji multikolonearitas dilakukan dengan melihat nilai tolerance, jika nilai tolerance $>0,10$ maka tidak terjadi multikolonearitas, begitu pula sebaliknya jika nilai tolerance $<0,10$ maka terjadi multikolonearitas. Atau dapat melihat nilai VIF, jika nilai VIF $<$ 10,00 maka tidak terjadi multikolonearitas begitupun sebaliknya jika nilai VIF $\geq 10,00$ maka terjadi multikolonearitas. Berdasarkan hasi uji multikolonearitas pada penelitian ini maka diperoleh hasil bahwa nilai VIF semua variabel independen dalam penelitian ini $<10,00\left(\mathrm{X}_{1}\right.$ dan $\mathrm{X}_{2}$ yaitu 1,511< $10,00)$.

\section{Hasil Uji Regresi Linier Berganda}

Uji regresi pada penelitian ini digunakan untuk menguji seberapa besar pengaruh harga jual $\left(\mathrm{X}_{1}\right)$ dan tingkat margin $\left(\mathrm{X}_{2}\right)$ terhadap pengambilan keputusan pembiayaan murababah (Y) pada BMT As'Adiyah Sengkang. Kriteria penilaian yaitu dengan nilai signifikansi 0,1 (10\%), jika nilai signifikansi F atau t statistiknya $\leq 0,1$ maka ada pengaruh signifikan variabel independen terhadap variabel dependennya, jika $\mathrm{f}>0,1$ maka tidak ada pengaruh signifikan.(MARDIATMOKO, 2020) Perangkat yang digunakan untuk uji regresi pada penelitian ini adalah menggunakan program SPSS versi 21. Adapun hasi uji regresi yang diperoleh adalah :

Tabel 3 : Coefficients ${ }^{\mathrm{a}}$

\begin{tabular}{|c|c|c|c|c|c|c|c|}
\hline \multirow[t]{2}{*}{ Model } & \multicolumn{2}{|c|}{$\begin{array}{c}\text { Unstandardized } \\
\text { Coefficients } \\
\end{array}$} & \multirow{2}{*}{$\begin{array}{c}\text { Standardized } \\
\text { Coefficients }\end{array}$} & \multirow[t]{2}{*}{$\mathrm{T}$} & \multirow[t]{2}{*}{ Sig. } & \multicolumn{2}{|c|}{ Collinearity Statistics } \\
\hline & B & Std. Error & & & & Tolerance & VIF \\
\hline (Constant) & 24,391 & 2,496 & & 9,772 &, 000 & & \\
\hline Harga jual & ,263 & ,214 & ,173 & 1,230 & ,223 & ,662 & 1,511 \\
\hline Tingkat Margin &,- 436 & ,205 &,- 299 & $-2,131$ &, 036 & ,662 & 1,511 \\
\hline
\end{tabular}

Sumber data primer: diolah tahun 2019

Tabel 4: Model Summary

\begin{tabular}{|c|c|c|c|c|}
\hline Model & $\mathrm{R}$ & $\mathrm{R}$ Square & Adjusted R Square & Std. Error of the Estimate \\
\hline 1 &, $244^{\mathrm{a}}$ &, 059 &, 033 & 1,850 \\
\hline
\end{tabular}

Banco, Volume 2, Mei 2020 


\section{Reni Furwanti}

a. Predictors: (Constant), Tingkat Margin, Harga jual

Sumber data primer: diolah tahun 2019

Berdasarkan hasil uji regresi pada kolom 2 di atas, persamaan regresi dalam penelitian ini dapat dirumuskan dan dijabarkan sebagai berikut:

\section{$Y=24,391+0,263$ Harga jual - 0,436 Tingkat Margin}

a. Nilai koefisien konstantanya sebesar 24,391 artinya jika $X_{1}$ dan $X_{2}$ nilainya nol, maka tingkat pengambilan keputusan nasabah pembiayaan murababah pada BMT As'adiyah Sengkang adalah sebesar 24,391\%.

b. Koefiensi regresi $\mathrm{X}_{1}$ sebesar $+0,263$ menyatakan bahwa jika variabel lainnya tetap dan variabel harga jual $\left(\mathrm{X}_{1}\right)$ mengalami kenaikan 1\%, maka harga jual $\left(\mathrm{X}_{1}\right)$ mengalami peningkatan sebesar $0,263 \%$. Koefiensi bernilai positif berarti terjadi hubungan positif antara harga jual dengan pengambilan keputusan pembiayaan murabahah, semakin tinggi harga jual maka semakin nasabah semakin berhati- hati dalam mengambil pembiayaan murabahah pada BMT As'adiyah Sengkang.

c. Koefiensi regresi $\mathrm{X}_{2}$ sebesar $-0,436$ menyatakan bahwa setiap bahwa jika variabel lainnya tetap dan variabel tingkat margin $\left(\mathrm{X}_{2}\right)$ mengalami kenaikan 1\%, maka tingkat margin akan mengalami penurunan sebesar 0,436 . Koefiensi bernilai negatif artinya terjadi hubugan negatif antara tingkat margin dengan pengambilan keputusan pembiayaan murabahah, semakin tinggi tingkat margin maka semakin menurun minat nasabah/ anggota untuk mengambil pembiayaan murabahah pada BMT As'adiyah Sengkang.

Untuk mengetahui seberapa besar pengaruh harga jual dan tingkat margin terhadap pengambilan keputusan nasabah pembiayaan murababah dapat dilihat pada Tabel 4 di atas, dapat diketahui bahwa harga jual dan tingkat margin berpengaruh positif terhadap keputusan nasabah adalah sebesar 59\% sedangkan $41 \%$ keputusan nasabah dipengaruhi oleh variabel lain yang tidak diteliti.

\section{Hasil Uji Hipotesis}

Uji t digunakan untuk menguji secara parsial masing- masing variable. Kriteria penilaian yang digunakan dalam penelitian ini adalah dengan membandingkan nilai thitung dengan $t_{\text {tabel. }}$ (Sriwijayanti, 2021) Apabila nilai thitung $>$ ttabel maka terdapat pengaruh, begitupun sebaliknya jika $\quad t_{\text {hitung }}<$ $t_{\text {tabel }}$ maka tidak terdapat pengaruh. Secara parsial harga jual berpengaruh signifikan tehadap pengambilan keputusan pembiayaan murabahah karena $t_{\text {tabel }}>t_{\text {hitung }}(1,230>0,233)$. Sedangkan tingkat margin tidak berpengaruh signifikan terhadap pengambilan keputusan pembiayaan murabahabpada BMT As'adiyah Sengkang $\left(\mathrm{X}_{2}\right)$ menunjukkan $\mathrm{t}_{\text {tabel }}<\mathrm{t}_{\text {hitung }} \quad(-0,131<0,36)$.

Uji $F$ digunakan untuk mengetahui pengaruh variabel bebas secara bersama-sama (simultan) terhadap variabel terkait. Penggunaan taraf signifikansi yang digunakan dalam penelitian ini adalah 0,05 atau $5 \%$. Hasil uji $\mathrm{F}$ dapat dilihat pada tabel ANOVA dalam kolom sig. Jika nilai signifikansi $<$ taraf signifikansi (penelitian ini menggunakan taraf signifikansi 0,05) maka dapat dikatakan terdapat pengaruh yang signifikan secara bersama- sama antar variabel bebas terhadap variabel terkait. Begitupun sebaliknya jika nilai signifikansi $>0,05 \mathrm{mka}$ tidak terdapat pengaruh yang signifikan. Secara simultan, dapat diketahui bahwa nilai signifikansi variabel $\mathrm{X}$ adalah $0,000<0,05$ maka dapat dikatakan terdapat pengaruh yang signifikan secara bersama- sama antara variabel harga jual $\left(\mathrm{X}_{1}\right)$ dan tingkat 
margin $\left(\mathrm{X}_{2}\right)$ terhadap pengambilan keputusan pembiayaan murabahah (Y) pada BMT As'adiyah Sengkang.

\section{Pembahasan}

Berdasarkan rangkaian pengujian di atas maka diperoleh hasil interpretasi secarara mendalam mengenai hubungan antar variabel sebagai berikut:

a. Analisis Pengaruh Harga jual terhadap Pengambilan Keputuan Nasabah pada Pembiayaan Murabahah BMT As'adiyah Sengkang.

Penetapan harga jual merupakan aspek yang sangat penting dalam kegiatan pemasaran. Harga jual menjadi sangat penting untuk menentukan harga produk pembiyaan murabahah yang dapat bersaing di pasaran. Harga jual yang diterapkan pada BMT As'adiyah sengkang tidak jauh berbeda dari lembaga keuangan lainnya. Di mana harga jual objek pembiayaan diambil dari harga beli barang pada supplier ditambah dengan biaya yang dikeluarkan hingga barang tersebut sampai ke tangan nasabah. Pihak BMT juga memiliki andil dalam melakukan survey harga di pasaran dan memilih supplier dengan penawaran harga terendah menggunakan untuk meningkatkan minat nasabah dalam pembiayaan murabahah pada BMT As'adiyah Sengkang.

Berdasarkan Tabel 1 dan 2 mengenai hasil uji regresi linier berganda, dalam penelitian ini dikemukakan bahwa variabel harga jual memiliki pengaruh yang signifikan terhdap pengambilan keputusan nasabah. Hal tersebut sejalan dengan teori yang mengemukakan bahwa variabel penetapan harga jual mempengaruhi keputusan pembiayaan murabahah. Di samping itu harga jual produk mampu menarik minat nasabah pembiayaan seperti adanya harga discount atau promo atau strategi harga lembaga keuangan terkait. Yang menjadi salah satu perbedaan adalah penyebutan istilah harga jual, di mana dalam penelitian ini menggunakan istilah harga jual sebagai salah satu indikator dari penentuan harga jual produk pembiayaan murabahah secara menyeluruh.(Sholeh \& Fauzia, 2021)

Pengaruh signifikan yang diperoleh dalam penelitian ini didasarkan atas prosedur penetapan harga jual pada BMT As'adiyah Sengkang yang diambil dari harga awal atau harga asli dari produsen atau dilihat dari kisaran harga di pasaran. Maka dari itu pihak BMT diharuskan untuk jeli dalam memili produsen yang dapat memberikan keuntungan baik untuk nasabah maupun untuk pihak BMT Sendiri. Di samping itu, nasabah diberikan kebebasan untuk memilih supplier dengan harga terendah untuk memperoleh objek murabahahnya. Dengan demikian pemberian tuposksi tersebut dapat meningkatkan minat nasabah.(Adalah \& Fadllan, 2016)

\section{b. Analisis Pengaruh Tingkat Margin terhadap Pengambilan Keputuan Nasabah pada Pembiayaan Murabahah BMT As'adiyah Sengkang.}

Tingkat margin merupakan faktor yang ada dalam menentukan berapa keuntungan yang diperoleh. Dalam penentuan margin ini memiliki perhatian yang lebih dari nasabah yang akan melakukan transaksi pembiayaan murabahah. Margin juga merupakan faktor dari terbentuknya perolehan akhir dari harga jual suatu objek pembiayaan murabahah(Sholeh \& Fauzia, 2021). Hal tersebut disebabkan karena adanya suatu perbedaan kebijakan dalam penentuan margin pada BMT As'adiyah dibandingkan dengan lembaga keuangan lainnya. Sehingga tinggi rendahnya tingkat margin tidak memberikan pengaruh yang 


\section{Reni Furwanti}

signifikan terhadap minat nasabah. Di mana penetapan margin pembiayaan murabahah pada BMT As'adiyah Sengkang masih berdasarkan aspek kondisional, seperti aspek waktu dan karakteristik nasabah. (Bernet \& Montero Fernández, 2021)

Hasil uji regresi linier berganda pada penelitian ini menunjukkan bahwa tingkat margin tidak berpengaruh signifikan terhadap keputusan nasabah, hal tersebut sejalan dengan hasil temuan penelitian yang dikemukakan oleh bahwa tingkat margin tidak berpengaruh signifikan terhadap keputusan nasabah. Hal tersebut dapat disebabkan oleh beberapa aspek. Berdasarkan hasil observasi di lapangan, peneliti menemukan fakta tentang alasan tingkat margin tidak berpengaruh signifikan terhadap keputusan nasababah, beberapa di antaranya sebagai berikut:

1) Nasabah pada BMT As'adiyah Sengkang kurang memahami prosedur penetapan margin

2) Karakteristik nasabah pada BMT As'adiyah lebih mengutamakan pola pikir rasionalitas muslim sebagai acuan penentuan keputusan (masyarakat sekitar cukup meminati lembaga keuangan syariah dibandingkan konvensional).

3) Sebagaian besar nasabah masih beranggapan bahwa margin itu adalah hak preorigatif pihak lembaga keuangan yang tidak bisa diganggu gugat.

Meskipun hasil pengujian secara persial menunjukkan bahwa tingkat margin tidak berpengaruh secara signifikan terhadap pengambilan keputusan pembiayaan murabahah, namun margin tetap memiliki pengaruh dalam menarik minat nasabah terlebih lagi penetapan margin pada BMT As'adiyah Sengkang sangat fleksibel dengan kondisi nasabah. Di samping itu, margin juga merupakan faktor penentu dalam penentuan akhir harga jual secara menyeluruh.(Furwanti, 2020)

Penetapan margin pada BMT As'adiyah Sengkang ditetapkan dengan memberikan kesempatan kepada nasabah/ calon nasabah untuk melakukan negoisasi sebelum akad dilakukan. Dalam negoisasi dijelaskan mengenai penetapan margin yang ditawarkan oleh nasabah dan hal- hal yang terkait dengan alasan penetapan margin tersebut. Salah satu pertimbangan penetapan margin adalah loyalitas nasabah, di mana nasabah prioritas atau nasabah yang sudah diakui kelancaran pembayarannya diberikan tingkat margin yang lebih rendah dibandingkan dengan nasabah baru yang ingin mengambil pembiayaan murababah. (Rahman \& Humaira, 2019)

\section{c. Analisis Pengaruh Harga jual dan Tingkat Margin terhadap Pengambilan Keputuan Nasabah pada Pembiayaan Murabahah BMT As'adiyah Sengkang.}

Secara parsial harga jual berpengaruh signifikan terhadap keputusan nasabah, sedangkan tingkat margin tidak berpengaruh signifikan. Meskipun demikian jika diuji secara simultan dapat diketahui bahwa harga jual dan tingkat margin berpengaruh signifikan terhadap pengambilan keputusan nasabah(Ridwan Nurdin, 2021). Dari hasil tersebut diketahui bahwa harga jual dan tingkat margin merupakan hal yang harus mendapat perhatian lebih karena keduanya merupakan bagian penting dari pertimbangan untuk mengambil keputusan dalam hal menggunakan atau tidak menggunakan produk murabahah pada BMT As'adiyah Sengkang. Hal tersebut sesuai dengan asumsi bahwa jika harga jual dan tingkat margin mengalami kenaikan atau peningkatan maka akan mempengaruhi kenaikan harga jual.(Muneeza et al., 2020) Di mana semakin tinggi harga jual objek murabahah maka semakin menurun minat nasabah dalam menggunakan pembiayaan murabahah tersebut, begitupun sebaliknya jika harga jual menurun maka minat nasabah akan meningkat untuk menggunakan produk nasabah tersebut. Tapi di sisi lain pihak BMT yang bersangkutan juga harus mempertimbangkan tupoksi harga jual dan tingkat 
margin untuk memperoleh harga jual yang ideal sehingga tidak mengalami kerugian(Millah \& Ayik Andriani, 2021)

\section{Kesimpulan}

1. Harga jual berpengaruh signifikan tehadap pengambilan keputusan nasabah pada pembiayaan murabahab BMT As'adiyah Sengkang. Hal tersebut disebabkan karena penentuan harga jual pada BMT terkait berlaku secara umum pada setiap anggota/nasabah pembiayaan sehingga secara otomatis jika harga jual mengalami peningkatan maka minat nasabah akan mengalami penurunan begitupun sebaliknya.

2. Tingkat margin tidak berpengaruh signifikan terhadap pengambilan keputusan nasabah pada pembiayaan murabahab BMT As'adiyah Sengkang. Hal tersebut disebabkan karena penetapan margin pada BMT terkait lebih mengarah kepada personalitas nasabah yang menjadikan setiap nasabah memperoleh perlakuan yang berbeda- beda terkait dengan penetapan margin.

3. Analisis regresi menunjukkan bahwa secara simultan, harga jual dan tingkat margin berpengaruh tehadap pengambilan keputusan nasabah pada pembiayaan murabahab BMT As'adiyah Sengkang. Hal tersebut disebabkan harga jual dan tingkat margin merupakan indikator yang menjadi pertimbangan nasabah dalam menggunakan pembiayaan murabahah karena merupakan faktor penentu dalam penentuan harga jual secara menyeluruh. 


\section{Reni Furwanti}

\section{Daftar Pustaka}

Diana Djuita, Dian Purnamasari. (2017). Analisis Penetapan Harga Jual pada Pembiayaan Murabahah berdasarkan Perspektif Islam di Koperasi Simpan Pinjam dan Pembiayaan Syariah (KSPPS) BMT Al-Falah Sumber. Al- Amwal: Jurnal Kajian Ekonomi dan Perbankan Syariah, Vol. 9, No. 1.

Hechem Ajmi, Hassanuddeen Abdul Aziz, Salina Kassim, Walid Mansour. (2019). Principal-Agent Preferences in Imperfect Market: Theoretical Analysis on Murabahah and Ijarah. JIMF: Jurnal of Islamic Monetary and Finance, Vol. 5, No. 1.

Hotimatul Adalah, F. F. (2016). Pengaruh Potongan Margin (Muqashah Ar-Ribhi) Terhadap Minat nasabah dalam Memanfaatkan Pembiayaan Murabahah di Bank Pembiayaan Rakyat Syariah (BPRS) Bhakti Sumekar (Studi Kasus di Kantor Cabang Bluto Sumenep). Iqtishadiah, Vol. 3. No. 1.

Muh. Fudhail Rahman, Aida Humaira. (2019). Position and Role of sharia Banks on Murabahah Contract Implementation. Bengkulu: MADANIA: Jurnal Kajian Keislaman, Vol. 23, No. 2.

Muhammad Ali Tamrin, Dedi Suselo. (2018). Implementasi Akad Murabahah dalam Penentuan Harga dan Margin Pembiayaan pada BMT di Tulungagung. Jurnal Iqtisaduna, Vol. 4, No. 1.

Adalah, H., \& Fadllan, F. (2016). Pengaruh Potongan Margin (Muqashah Ar-Ribhi) Terhadap Minat nasabah dalam Memanfaatkan Pembiayaan Murabahah di Bank Pembiayaan Rakyat Syariah (BPRS) Bhakti Sumekar (Studi Kasus di Kantor Cabang Bluto Sumenep). IQTISHADLA: Jurnal Ekonomi \& Perbankan Syariah, 3(1). https://doi.org/10.19105/iqtishadia.v3i1.1050

Ajmi, H., Abdul Aziz, H., Kassim, S., \& Mansour, W. (2019). PRINCIPAL-AGENT PREFERENCES IN IMPERFECT MARKET: THEORETICAL ANALYSIS ON MURABAHAH AND IJARAH. Journal of Islamic Monetary Economics and Finance, 5(1). https://doi.org/10.21098/jimf.v5i1.1050

Bernet, L., \& Montero Fernández, M. A. (2021). Margins. Revista de Senologia y Patologia Mamaria, 34. https://doi.org/10.1016/j.senol.2021.10.009

Djuwita, D., \& Purnamasari, D. (2017). Analisis Penetapan Harga Jual pada Pembiayaan Murabahah berdasarkan Perspektif Islam di Koperasi Simpan Pinjam dan Pembiayaan Syariah (KSPPS) BMT Al-Falah Sumber. Al-Amwal: Jurnal Ekonomi Dan Perbankan Syariah, 9(1). https://doi.org/10.24235/amwal.v9i1.1733

Fathorrahman, F., \& Nufus, K. (2021). Pemanfaatan Digital Marketing Pada Koperasi Dan Cara Koperasi Menghadapi Financial Technology (Studi Kasus pada BMT Al-Fath IKMI). Jurnal Ilmiah Feasible (JIF), 3(1). https://doi.org/10.32493/fb.v3i1.2021.1-12.7104

Furwanti, R. (2020). HARGA JUAL DAN TINGKAT MARGIN: PREFERENSI NASABAH 
DALAM MENGGUNAKAN PRODUK PEMBIAYAAN MURABAHAH BMT

AS’ADIYAH SENGKANG. BANCO: Jurnal Manajemen Dan Perbankan Syariah, 2(1).

https://doi.org/10.35905/banco.v2i1.1331

Harahap, S. A. R., \& Ghozali, M. (2020). Peran Baitul Mal Wa Tamwil (BMT) dalam Pengembangan Ekonomi Umat. HUMAN FAL AH: Jurnal Ekonomi Dan Bisnis Islam, 7(1).

Makkulau, A. R., \& Abdullah, M. W. (2017). PENERAPAN PRINSIP SYARIAH DALAM AKAD PEMBIAYAAN MURABAHAH PADA BANK MUAMALAT. Jurnal Iqtisaduna, 3(1). https://doi.org/10.24252/iqtisaduna.v3i1.4032

MARDIATMOKO, G.-. (2020). PENTINGNYA UJI ASUMSI KLASIK PADA ANALISIS REGRESI LINIER BERGANDA. BAREKENG: Jurnal Ilmu Matematika Dan Terapan, 14(3). https://doi.org/10.30598/barekengvol14iss3pp333-342

Melina, F. (2020). PEMBIAYAAN MURABAHAH DI BAITUL MAAL WAT TAMWIL (BMT). Jurnal Tabarru': Islamic Banking and Finance, 3(2). https://doi.org/10.25299/jtb.2020.vol3(2).5878

Millah, H., \& Ayik Andriani. (2021). ANALISIS PENETAPAN HARGA JUAL PADA PEMBIAYAAN MURABAHAH BERDASARKAN PERSPEKTIF ISLAM DI BMT UGT SIDOGIRI CAPEM PAJARAKAN (Studi Kasus Bank Syariah Mandiri KC Lumajang). AlIdarah : Jurnal Manajemen Dan Bisnis Islam, 2(1). https://doi.org/10.35316/idarah.2021.v2i1.6879

Muneeza, A., Fauzi, M. F., Bin Mat Nor, M. F., Abideen, M., \& Ajroudi, M. M. (2020). House financing: contracts used by Islamic banks for finished properties in Malaysia. Journal of Islamic Accounting and Business Research, 11(1). https://doi.org/10.1108/JIABR-04-2017-0057

Rahman, M. F., \& Humaira, A. (2019). Position and Role of Sharia Banks on Murabahah Contract Implementation. Madania: Jurnal Kajian Keislaman, 23(2).

Ridwan Nurdin, S. ainun J. (2021). Analisis Rate Margin Murabahah pada Transaksi Jual beli Rumah Subsidi KPR BTPN syariah dalam Perspektif Hukum Islam (Suatu penelitian pada BTN syariah KC Banda Aceh). Al-Murdrabah, 3(1).

Sakum, S. (2021). IMPLEMENTASI AKAD MURABAHAH PADA PRODUK PEMBIAYAAN MURABAHAH DI KOPERASI SIMPAN PINJAM DAN PEMBIAYAAN SYARIAH BAITUL MAAL WAT TAMWIL FAJAR CABANG BEKASI. Jurnal Ekonomi Syariah Pelita Bangsa, 6(01). https://doi.org/10.37366/jespb.v6i01.173

Sholeh, K., \& Fauzia, A. N. (2021). Pengaruh Promosi, Nilai Syari'ah, dan Prosentase Margin Terhadap Minat Nasabah untuk Mengajukan Pembiayaan Murabahah di KSPPS BMT Mandiri Sejahtera Cabang Pangean. Jurnal Ekonomi Syariah, 4(1).

Sriwijayanti, H. (2021). Analisis Pengaruh Transparansi, Akuntabilitas Dan Pemanfaatan Sistem Informasi Akuntansi Keuangan Daerah Terhadap Pengelolaan APBD (Studi Persepsi Pengelola Apbd Skpd Dinas Pemerintah Kota Padang). Jurnal Ekobistek. 


\section{Reni Furwanti}

https://doi.org/10.35134/ekobistek.v7i1.6

Sudjana, K., \& Rizkison, R. (2020). Peran Baitul Maal Wat Tamwil (BMT) dalam Mewujudkan Ekonomi Syariah yang Kompetitif. Jurnal Ilmiah Ekonomi Islam, 6(2).

https://doi.org/10.29040/jiei.v6i2.1086

Yusup, F. (2018). Uji Validitas dan Reliabilitas Instrumen Penelitian Kuantitatif. Jurnal Tarbiyah: Jurnal Ilmiah Kependidikan, 7(1). https://doi.org/10.18592/tarbiyah.v7i1.2100 